\title{
Wild Bulls, Discarded Foreigners, and Brash Champions: US Empire and the Cultural Constructions of Argentine Boxers Daniel Fridman \& David Sheinin
}

In the past decade, scholars have devoted growing attention to American cultural influences and impact in the Philippines, Panama, and other societies where the United States exerted violent imperial influences. ${ }^{1}$ In countries where US imperialism was less devastating to local political cultures, the nature of American cultural influence and the impact such force had is less clear and less well documented. ${ }^{2}$ Argentina is one such example. American political and cultural influences in twentieth-century Argentina cannot be equated with the cases of Mexico or the Dominican Republic, nor can they be said to have had as profound an impact on national cultures. At the same time, after 1900, US cultural influences were pervasive in and had a lasting impact on Argentina.

There is, to be sure, a danger of trivializing the force of American Empire by confusing Argentines with Filipinos as subject peoples. Argentina is not a "classic" case of US imperialism in Latin America. While the United States supported the 1976 coup d'état in Argentina, for example, there is no evidence of Central Intelligence Agency (CIA) and US military backing on a scale equivalent to the 1964 military coup in Brazil or the 1973 overthrow of democracy in Chile. Although American weapons and military strategies were employed by the Argentine armed forces in state terror operations after 1960, there was no Argentine equivalent to the massive US intervention in state-sponsored counterinsurgency warfare in El Salvador or Guatemala. ${ }^{3}$ While there was substantial US cultural influence in Argentina in the twentieth century, there was no devastating US presence matching those of US ecological imperialism in Panama, US influenced cults of masculinity in the Dominican Republic, or the American push for a contradictory, colonial modernity in Puerto Rico. ${ }^{4}$

Even so, this article argues that American cultural influences in Argentina and, more specifically, the cultural construction of Argentine boxers in the United States are notable for what they represent of US imperial cultures in both Argentina and Latin America more broadly. Those cultures have exoticized Latin Americans as a key component of dominance, had profound influences on Argentine society, and have tied the Argentine experience, in the face of US expansion, to the experiences of other nations in the hemisphere. ${ }^{5}$ Cultural exchange, according to the historian Penny M. Von Eschen, "was the commodity that closely pursued the quintessential Cold War commodities, oil and uranium, along with many others critical to America's seductive abundance." At times-as in the case of the music of Louis Armstrong or the paintings of Jackson Pollock - cultural expansion was a cornerstone of American foreign policy. It was promoted as actively by the US government as economic and political expansion. But just as often, cultural expansion functioned independently of US government 
policy-making objectives. Reinhold Wagnleitner has argued that some of the more powerful cases of US cultural expansion ran contrary to dominant ideologies in the United States and to elite projections of American culture. Many peoples around the world celebrated and adopted what they understood as elements of African American popular culture, for example, precisely because in a civil rights era context, they imagined it to run counter to mainstream American culture. To some degree, Argentine boxers and fans viewed American boxing as African American culture. At the same time, as an American cultural influence, boxing reached Argentina neither as an expression of State Department policy nor as an antidote to US dominance. ${ }^{?}$

With the possible exception of Hollywood films, there has been no more important point of cultural contact between Argentina and the United States than boxing. The wildly popular world of Argentine boxing was built in large measure with a US boxing aesthetic starting with the early-twentieth-century construction of Luna Park, the principal boxing arena in Argentina. Equivalent to, and perhaps even more important than Madison Square Garden in Argentine boxing imagery, the arena was named for the first amusement park. Opened in 1903, the original Luna Park in Coney Island inspired dozens of copies in the United States and other countries. "Luna Park" quickly became part of an international lexicon that stressed pleasure and desire and was an early example of the colonizing force of American popular culture. ${ }^{8}$

This article will consider two intertwined topics. The first is the construction of the imagery of Argentine boxers in the United States and the varieties of Argentine boxers' immigrant experience in North America. After 1920, as a product of the commodification of boxing and following American models, Argentine fighters routinely sought success, fame, and fortune in the United States. Their arrival in North America over successive generations promoted the cultural construction of an exoticized Argentine boxer as a masculine ideal of power and brute force, parallel to the imagery of African American pugilists and boxers from many other countries. The bilateral boxing relationship was so intense that it helped define what would emerge as the only lasting popular image of an "Argentine" in the United States — that of the Argentine boxer." However, this idealized construction concealed the realities of the boxing migration. Where the imagery was one of a powerful foreigner who threatened American boxing supremacy, Argentine boxers in the United States were seldom like their image. More often than not, boxers who went to the United States were beaten down physically and financially during their time in North America.

Second, this article will argue that the presence of Argentine boxers in the US forged a sense in Argentina that the former were leading actors on the American boxing scene. This, in turn, shaped Argentine boxing cultures and selfimages. The bilateral boxing relationship not only helped forge popular American views of Argentines, but American cultural models of the boxer also produced the 
character and styles of individual boxers in Argentina. Americans exercised a form of cultural power through boxing in a manner that promoted US ideals and behaviors more broadly. ${ }^{10}$

\section{Wild Bulls}

In 1956, Humphrey Bogart starred in The Harder They Fall. The film-Bogart's last and one of a long line in the genre of Hollywood boxing movies ${ }^{11}$ - tells the story of the down-and-out boxing writer Eddie Willis, who falls still further when he comes under the sway of the notorious New York underworld crime figure, Nick Benko. Benko hires Eddie as press manager for up-and-coming boxer Toro Moreno. Brought in from Argentina, Toro Moreno is a contradiction. An aweinspiring giant of a man, Moreno is unable to land a hard punch, much less win a fight that is not fixed. In what plays out as a universal boxing morality tale, Benko is not interested in what is best for "his" boxer. Under Eddie's tutelage, the Argentine can and will overcome his athletic limitations. Moreno fights his way to the top with the help of matches that are bought, a complicit press, and Eddie's encouragement. Faced in the end with a title shot-a fight that cannot be won through a fix-Moreno loses badly, pummeled by his superior opponent. Dejected and decided on a return to Argentina with the "fortune" he had won boxing in the United States, Moreno learns that, after expenses, he is left with all of $\$ 49.07$. In the end, the story is redemptive but not for the boxer. Eddie finds his moral compass by returning to Toro the money he had won. He dedicates himself once more to his journalistic calling by decrying the influence of organized crime on boxing.

Based loosely on the career of the Italian boxer Primo Carnera, the film reflects a Hollywood orientalist tradition that has tended to reduce American multi-ethnicity to a bipolar treatment of race, in this case through white-versus Hispanic combat. ${ }^{12}$ That tradition played an important parallel role in what the historian Gerald Horne has called a "praxis of white supremacy" in US foreign relations. After 1890, increasingly complicated foreign and domestic ideals of American whiteness were juxtaposed with equally complex constructions of foreign blackness to help produce an ideology and set of policy imperatives designed to impose American dominance on subject peoples. ${ }^{13}$ The openness and blatancy of American racism in foreign relations began to fade after the Second World War, however new American cultural constructions of race and superiority were formed. In the context of the defeat of Japan, new Hollywood portrayals of Asians were produced, and US policy makers' increasingly associated race with political subversion in light of the activism of Martin Luther King, Jr. and Paul Robeson. ${ }^{14}$ Moreover, The Harder They Fall anticipated the so-called post-1960 "muscle gap," an anxious US government discourse suggesting that the growing physical weakness of white American men was becoming a threat to national secu- 
rity. Traditionally the most masculine of American pastimes, the corruption of boxing reflected the distortion of the white American body and of an American society ripe for the picking by wily Communists. ${ }^{15}$

Between 1930 and 1960, boxing movies represented roughly a third of all Hollywood films with a "sport" theme, a proportion higher than that registered by any other sport film genre. Hollywood producers used boxing as a film medium through which to filter moralities and ideological touchstones to a large viewing public. ${ }^{16}$ The film's transformation of an Italian into an Argentine reflects a duality in boxing as a key point of US-Argentine cultural contact. The first element in the duality is Argentine boxing as a cultural representation in the United States. The film's Argentina allusion of dull masculinity and exotic power dates explicitly to 1923 when the Argentine Luis Angel Firpo challenged Jack Dempsey for the world championship at the Polo Grounds in New York. As a fighter, Firpo differed enormously from Toro Moreno. The fictional Moreno was a naif and a lumbering slugger with little ability. Firpo was a powerful hitter and a brilliant boxer who, by many accounts, should have won the Dempsey fight; after hitting Dempsey so hard in the first round the champ flew through the ropes and onto a journalist's typewriter. ${ }^{17}$ While Moreno's fictional American sojourn typifies the boxer's financial travails, after the Dempsey fight Firpo quietly took all his winnings and went home. Born to working class parents in Buenos Aires, Firpo was far more financially astute than the majority of his boxing contemporaries. Before his match with Dempsey, he had loaned his name to a variety of products (many imported from the United States) including Firpo Form-Fitting Shoes and Firpo Fedoras. Having earned \$156 250 for the Dempsey fight, he signed an agreement the next morning to import a custom-designed sports car, the Firpo Stutz Bearcat, into Argentina. Red with a bull's head painted on the side, the car was sold exclusively by Firpo. At his death in 1960, Firpo was worth $\$ 5$ million and owned more than 205000 acres of land on his five estancias. ${ }^{18}$

If Firpo was nothing like Toro Moreno, where is the connection? The American image of the Argentine boxer here and elsewhere is more cultural construction than realistic assessment of boxing as practiced by Argentines. What Americans remembered of Firpo in the decades that followed the Dempsey fight had less to do with the Argentine's ability as a fighter than with two other factors. First, after 1920, as US power in Latin America grew quickly, Americans distinguished less and less between Latin American nations and societies. In the 1920s, Americans held an image of Argentina as distinct from Caribbean basin countries. By the Cold War era, that sense of difference had faded. This was manifest most bluntly in the growing rigidities of US foreign policy that increasingly tended to view any and all Latin American reform movements as a monolithic expression of Soviet Communism. ${ }^{19}$ Argentine boxing became a cultural equivalent to this American melding of Latin American political cultures. The historical memory of Firpo in the United States was enmeshed with qualities of Dominican, Puerto 
Rican, Cuban, and Mexican boxers as Latin types in the ring, "willing to wade into an opponent and break him apart, one body shot at a time."20

Second, in losing to Dempsey, Firpo played a brief but key role as both an Argentine and as a Latin American, in helping to build Dempsey's Jazz Age image. After and partly as a result of the Firpo fight, Dempsey became the most famous athlete in the world. According to writer Roger Kahn, Damon Runyon's nickname for Firpo, "the Wild Bull of the Pampas," was a "triumph of imagery over accuracy." tion with an exotic, ethnically distinct, violent, foreign intruder. This type stands in contrast to what Fernando Delgado describes as the "hegemonic masculine male athlete" in the United States, a white favorite of the press. This athletic ideal is embodied, for example, in the baseball pitcher Nolan Ryan whose athletic excellence is complemented by an iconic representation of rugged individualism and the Western cowboy. He is "an idealized male hero-silent, powerful, menacing, successful - a character rooted in rural America." 22 In athletics, and in boxing more specifically, images of race, ethnicity, and power followed a larger set of imperial constructions that posited Manifest Destiny and subsequent American versions of the logic of imperial projects as a question of racial inevitability. ${ }^{23}$

For thousands of fight fans in the United States and beyond, the wild bull image set the stage for a colossal struggle. During Dempsey's rise, sports writers like Ring Lardner, Grantland Rice, and Paul Gallico crafted the champ in print as a ferocious and aggressive pioneer spirit, raised in Colorado mining towns and with early fight experience in western hobo camps. The growing urban newspaper readership that followed boxing understood and transformed the frontier imagery into one that cast Dempsey as less a brute, and more an American individualist, taming savagery and bringing down powerful enemies. ${ }^{24}$

American journalists placed distance between Dempsey and his early tough guy image by building Firpo into the champ's most brutal potential opponent, precisely the sort of opponent that Demspey had been before his initial title shot. Only now, with Dempsey's role reversal, the "bad guy" brute was no longer a thug from the Wild West but a savage fighter from the Argentine plains. News stories concentrated on Firpo's Toro Moreno-like size as a representation of savagery-his six feet, three inch frame, his body weight of 230 pounds, his raw strength, and the unusual size of his shoulders and hands. Grantland Rice ranked Firpo the most dangerous contender Dempsey had faced, an "A rgentine Plesiosaurus" who "might have roamed the earth in the dim days beyond the rim of history." ${ }^{\prime 25}$ Before fighting Dempsey, Firpo had made a name for himself in "American" sports venues. He had beaten "Italian Jack" Herman at Ebbets Field, knocked out Bill Brennan at Madison Square Garden, and defeated Herman for a second time in Havana (that most American of 1920s playgrounds). Before the Dempsey fight, in an inspired move, fight promoter Tex Rickard matched Firpo against Jess "The Pottawatomie Giant" Willard in what he called the battle of the 
giants. Rickard predicted an unprecedented gate, partly because of the support generated among Americans of "Spanish and Italian blood" in the Argentine Firpo. ${ }^{26}$ The fight was a brawl. While federal tax officials counted a paid attendance of 75 712, many thousands more crashed the gate. The story of Firpo's crushing victory on a ten-count in the eighth round made the lead in the New York Times, which described Firpo's savage unrelenting drives to the body.

The stage was set for a Firpo-Dempsey match-up at the Polo Grounds. The unprecedented million-dollar gate showed the extent to which boxing had quickly become big business in the 1920s. Journalists fell over themselves in painting Firpo as an Argentine and as a South American. Small details were assembled into a national image. His car, according to the New York Times, was detailed with both the Argentine coat of arms and the head of a wild bull. ${ }^{27}$ When Firpo, who had hired Jack Johnson as a sparring partner, fired his American trainer Jimmy De Forrest on the advice of a former Argentine trainer Félix Bunge, all hell broke loose in the press. The change supposedly marked a rejection of American training methods in favor of their Argentine equivalents. Despite Bunge's denials and his insistence that Firpo, in fact, depended on "American" boxing methods, the New York Times reported that the fight would pit an Argentine fighting style against Dempsey's American techniques and training. The newspaper even suggested that were Firpo to win, Americans would have to rethink the Monroe Doctrine and its meaning. ${ }^{28}$

Firpo's South American exoticism and masculinity was built around the supposed mysteries of his possible success. The Argentine seemed brutish, according to the New York Times, even laughable on first glance. ${ }^{29}$ But on further observation, his vulgarity seemed a form of intelligence that was incomprehensible to his opponents, the reflection of a style that had never been seen before "this side of the Panama Canal. ${ }^{30}$

While opening a dialogue regarding American Imperialism in the Americas, the fight forged Firpo's place as an Argentine fighter in the American popular imagination. The New York World credited Tex Rickard's unrelenting prefight publicity with having created the widespread popular image of the "Wild Bull of the Pampas" while the Brooklyn Eagle mused, as had the New York Times earlier, at "what might have happened to the Monroe Doctrine if Firpo had won." Boyden Sparkes of the New York Tribune suggested that only a duel between George Washington and Simon Bolívar might have generated equivalent attention. Interest in the fight might have made Latin Americans "less resentful of the Monroe Doctrine, of marines in Nicaragua, and Yankee-as they interpret itimperialism." As a result of the fight, he went on, Latin Americans would begin to buy "American automobiles, American drugs, American hardware, [and] American clothing." ${ }^{32}$ The Washington Post returned to Firpo's identity in arguing that had the Argentine been able to "think" as an American in the ring, the fight would have been his. ${ }^{33}$ 
To be sure, what Sparkes wrote was an exaggeration of Firpo's potential impact on US-Latin American relations. But the Dempsey-Firpo fight opened a vibrant new avenue in US-Argentine contacts; it ushered in decades of bilateral contact in the world of boxing and helped forge a key figure in American popular culture, the savage Latin American. From the outset, and as suggested again more than thirty years later in The Harder They Fall, Americans understood Argentine boxers as a cultural invention. ${ }^{34}$ But that cultural invention was built after Firpo and based on a small migration of Argentine boxers to the United States. From the 1920s through the present, the United States has been the principal destination of Argentine boxers who left their country to fight. As depicted in The Harder They Fall, burgeoning boxing markets in Chicago, New York, and Los Angeles each required their share of "losers"-boxers with high hopes but whose prospects were grim. A majority of fighters were expected to lose by those who bankrolled their fights. They were paid to be stepping stones in the climb to a title bout for another boxer. ${ }^{35}$

Opportunities for fighters, both winners and losers, explain only in part the attraction of the United States for Argentine boxers. As in many migratory processes from peripheral regions to a core metropolis, the link between Argentina and the United States in boxing was built over the long term through social networks. Argentine boxers who moved to the United States became contacts for potential new migrants in future years. Relations between Argentine managers and American fight promoters became more common over the twentieth century. Argentina became a country from which Americans regularly recruited boxers for occasional fights in the United States. After 1950, a number of Argentines launched their careers in the United States without having fought professionally in their homeland. A small number decided to stay in North America on their retirement from the ring. In and around New York City, these men built a small community of Argentine boxers, ex-boxers, their families, their business contacts, and their friends. The lives of these men, though, had almost nothing common with Firpo's successes.

\section{Boxing Identities and Argentine Boxers in the United States}

Over the past hundred years, in Europe and the Americas the difference between the amateur and the professional boxer has been enormous, much more so than in other sports. The amateur-professional distinction speaks to the relationship between boxing and class. In the late-nineteenth and early-twentieth centuries, in Argentina, the United States, and elsewhere, amateur boxing and Marquis of Queensbury rules were fostered by elites in answer to unregulated bare knuckle boxing, street fighting, and dueling. ${ }^{36}$ During the 1910s, for example, the Argentine Jorge Newberry came to define elite ideals of nation not only for what he represented, but for what his actions and image countered. ${ }^{37}$ 
As an aviator whose exploits generated Charles Lindbergh-like fame in Argentina, and as a gentleman amateur boxer, Newberry characterized a modern and progressive, manly, European-looking Argentina. But this imagery also challenged a national identity that elites feared, that of poverty, immigrant communities, and the countryside as uncivilized, all elements that made up the elite-constructed identity of those who practiced and followed bare-knuckle boxing. In Argentina, despite the efforts of boxing authorities to regulate and civilize the sport through the Argentine Boxing Federation (FAB), professional boxing continued to represent the legacy of street fighting. Through the twentieth century, professional boxers have defined a national identity tainted by the uncivilized. In 2003, eighty-year old referee Oscar Seleme expressed his distaste for the character and image of boxing in the present by recalling the last era of "great" boxers as the 1950s. Here greatness is measured not only in skill and results but also in character and deportment. Seleme's nostalgia for a more civilized past in boxing and society is equivalent to similar laments among many Argentines through the twentieth century about the preceding generation. ${ }^{38}$

The end of an era of greatness in Argentine boxing after the 1950s, as seen by Seleme, coincides with a sharp decline in amateur boxing. That decline is seen not only in the lack of attention by media and fans, who massively embraced professional boxing, but is also expressed in its reduced success in Olympic competitions. Boxing has brought the country more Olympic medals than any other sport- twenty-four out of the fifty-nine medals Argentine athletes have won in all sports-but twenty of them were received in the quarter century between Paris 1924 and Helsinki 1952. After the 1950s, amateur boxing became mostly an inevitable stepping-stone towards professionalism. The centrality of national Olympic boxing teams that represented the colors of the country in athletic competitions was replaced by that of professional boxers, whose attachment to national identity was more complex. Unlike amateur teams, professional boxers-like Firpo earlier and others later-are not official "ambassadors," however, they nonetheless represent their homeland. Their identity is more open to complicated cultural constructions.

In December 1967, an article in The Ring magazine speculated that perhaps a climate conducive to soft skin in adults helped explain why British boxers were unable to take a punch or win world championships. Not only did the article revive a longstanding linkage between climate, civilization, and national or civic identity, but it posited an Argentine winning national glory for Great Britain. ${ }^{39}$ Recently arrived in London by way of a series of fights in Italy, the Argentine Eduardo Corletti held out the hope of a world heavyweight championship for Britain through his natural Argentine prowess, a Romantic Italian influence, and the force of British promotion. ${ }^{40}$ When he lost, Corletti's national identity as a boxer was blurred again. In The Ring he became an Italian based in London. ${ }^{41}$

Corletti's successive migrations created a confusion that did not occur for 
his Argentine contemporaries in the United States. For Argentine heavyweight Alexis Miteff, the dominated position of the immigrant boxer in the boxing business structure outweighed all other identities. "Do you know how much money I made in my fight with Muhammad Ali?" he asked in 2005: "three dollars." Miteff came to the United States in 1956 to launch his professional career. When he won the Pan-American amateur heavyweight championship the year before, Miteff had a number of offers to fight professionally. His manager would not let him go to the United States, afraid that Miteff would become a "slave" to his American handlers. Miteff's slavery metaphor is a reflection of what the sociologist Loï Wacquant calls one of the key figures with which boxers identify their place in the boxing market. Slavery, prostitution, and the traffic in animals are all forms through which boxers tend to understand their relationships-as traded commodities-with managers and matchmakers. ${ }^{43}$

For Miteff, "boxing is all business, here [in the United States] more than anywhere else. Here it's more against the boxer. They take ten percent for expenses, ten percent for the trainer, thirty-three percent for the manager. At the end of the year, the government takes what you don't spend up front. Why bother to box at all?" ${ }^{44}$ Almost forty years earlier, Miteff had expressed similar sentiments in an interview with the Los Angeles Times when he lamented his having come from Argentina at age nineteen believing that his American handlers would take care of his interests. He complained of his American managers' greed, their having put him up against the superior American boxer Archie McBride, and their having "almost killed me."

Like Firpo, the Argentine boxers who made a name for themselves in the United States later in the century were in the heavier weight classes. Heavyweights like Miteff, Oscar "Ringo" Bonavena, and Alejandro Lavorante all ran out of opponents in Argentina at the close of their amateur careers. Because the heavier weight categories were the most popular in the United States, there were more opportunities for more lucrative fights for Argentines than in their country of origin. There was also what Miteff and others perceived after the fact to be a higher level of exploitation and abuse of foreigners. Despite having warned him away from the United States and his likely enslavement, Miteff's manager subsequently negotiated a contract for his charge. What Miteff learned later was that for $\$ 10$ 000 , his rights had been sold to Hymie Wallman, a manager with ties to organized crime figure Frankie Carbo, who also held Sonny Liston's contract during the 1950s. Wallman had managed another Argentine heavyweight, César Brion, before finding himself in charge of Miteff. In 1958, when Carbo was investigated for illegal practices in boxing, it was discovered that Wallman had been buying referees in a number of fights, including two that Miteff had fought. ${ }^{46}$

Miteff insists he had no idea of what his manager was doing with him because, like Toro Moreno, he knew no English. After twelve victories, Miteff suffered his first lost to Mike DeJohn. Knowing at the time that he had trouble with 
taller fighters, and that DeJohn enjoyed a two-inch height advantage over him, Miteff wondered why this particular opponent had been chosen. But not knowing English, he said nothing.

According to boxer Sergio Victor Palma, most professional boxers are groomed and marketed as "losers," mostly without their own knowledge. Miteff's sense of the role he played for his most important bout with Muhammad Ali recognizes, at least in part, Palma's dictum. Miteff understood himself as his handlers' object: "Ali was moving up and they used me. Just look how they used me! [The promoter] Teddy Brener told Gil Clancy 'buy him [Miteff] and I'll put him up against Cassius Clay.' They didn't put me in the ring to win or to lose. I was there to fight. If I won, great. I lost, but no problem. He [Brenner] got his money.... Perfect for Ali. Because I was a bit of a name and he beat me." ${ }^{47}$ In retrospect, Miteff understood and explained what did not seem clear to him at the time - his own commodification as an Argentine boxer in the American market.

Unlike Miteff, boxers like Firpo and Bonavena won fame in Argentina by projecting an image of conquest in the United States, rejecting or taking advantage of their commodification. Firpo refused to hire a manager, a breach of business rules implicit to the North American boxing market. He also had his American fights filmed so as to be able to show them for profit in Argentina. Bonavena cultivated a brash, rebel's image to show his control of the circumstances surrounding his American fights. Jack Singer, Bonavena's first American manager, stopped working with the Argentine because of his contentious nature. Singer owned a restaurant on Manhattan's 42 ${ }^{\text {nd }}$ street where his charges would work when not training. The Argentine fighter Celedonio Lima reached New York (and the restaurant) just as Bonavena was leaving Singer's circle. According to Lima, Singer, "thank God, always spoke well of me. I came to him at a bad moment. Bonavena wouldn't give him the time of day. He threw his [Singer's] tables... He didn't want to work." ${ }^{\prime 4}$ Even in small details, like refusing to cut his hair before a fight, Bonavena practiced a boxer's bravado that drew both on an image of Argentine combativeness and his American surroundings-particularly the example of the pugnacious Cassius Clay. ${ }^{49}$

Boxers with larger-than-life public personae have frequently begun their careers under much less auspicious circumstances, and in a manner that, when considered in the context of young Argentine boxers arriving in the United States to be managed by tough-minded American promoters, has exacerbated the relationship of dominance and dependence. According to the Argentine amateur boxer Sergio Raso, there is a universal linkage between success in professional boxing and the boxer's willingness to turn himself (or, more recently, herself) over to a trainer's direction in all aspects of life. For a professional boxer to succeed, he or she must complement aggressiveness in the ring with a submissive quality. The boxer must accept unconditionally and without hesitation his trainer's every whim..$^{50}$ At age eleven, the Argentine world champion Juan Martín Coggi was 
knocking down adults in hastily organized street fights in the poor suburbs that ring Buenos Aires. Even though he emerged as a brilliant left handed boxer in the 1980s, Coggi fought his first professional bouts leading with his left, positioned as a right handed fighter. When, after several fights, his trainer figured out that Coggi was a lefty he asked him, puzzled, about his wrong-handed positioning. "That's what you told me to do," Coggi responded. ${ }^{51}$ In Argentina, there is an important correlation between submissiveness and class. In their rise to a world championship, Coggi, Sergio Victor Palma, Carlos Monzón, and Victor Galíndez all had in common ferocity in the ring, a notorious willingness to submit to the authority of their trainer, and working class origins of severe poverty. In the identity of an Argentine boxer, submissiveness and success have frequently correlated with poverty, the boxer's racial identity as a person of color, and the middle class, "white" identity of the trainer.

In some key regards, Bonavena cut an image antithetical to the docile and submissive boxer and, as such, represented a distinct national image in both the United States and Argentina. Like a majority of Argentine boxers, he came from a working class family that identified itself as Peronist. But Bonavena represented a very different working class identity from that of Galíndez or Monzón. Bonavena was white. He came from an Italian immigrant family with strong and longstanding neighborhood ties in Buenos Aires. Famously, Bonavena trained at and fought out of his neighborhood's club, "Huracán." Bonavena's identity stood in contrast to that of other boxers whose working class origins spoke to extreme poverty. Monzón and Galíndez represented a later migration to the city of Buenos Aires not from Europe, but from the interior of the country-a migration of "negros," as known by middle-class white Argentines.

Other champions defined an Argentine identity of strength and victory after their rise to prominence. But unlike Bonavena, their triumphs were not tied in part to the cultivation of an "American" boxer's brash identity. Justo Suárez in the 1930s and José María Gatica in the 1950s, were popular, talented, and even belligerent in their public expressions of confidence. Gatica was known to pace Buenos Aires's calle Florida before a fight. Decked out in a garish white suit he would hand out his business card to passers-by while predicting the round in which he would knock out his opponent. Gatica and Suárez, like Bonavena and Miteff, found their way to the United States both as a test of their boxing prowess and as a best chance for success, fame, and fortune. For Gatica and Suárez, the sojourn was brief and unsuccessful. Both suffered disillusionment in dramatic losses at Madison Square Garden, and were quickly forgotten in the United States. Bonavena's Argentine identity was enhanced and molded by his time in the United States. By contrast, Miteff's American failures contributed to his staying permanently in the United States. In the popular imagination in Argentina, for Suárez and Gatica-already successful before their arrival in New York, unlike Miteffthe Madison Square Garden defeats demarcate the limits of the possible for an 
Argentine boxer up against the American boxing juggernaut.

Like other boxers, Argentine and otherwise, who had fallen on hard times, Miteff took what work he could get in the United States. In October 1961, he lost the most important fight of his career to Muhammad Ali in Louisville, Kentucky, a technical knock-out in the sixth round. One month later in Long Island, a cut over his left eye forced Miteff to call his fight with Ray Batey. After the fight he announced his retirement and vacated his South American championship. Less than a year later, in a jarring indication of the proximity of professional boxing to its cultural representations, Miteff appeared as Anthony Quinn's double in the film Requiem for a Heavyweight. It was a remarkable role for the newly retired Argentine with no prospects. "They beat him... they broke him... they betrayed him..." read the film's trailer, "but they could not crush the towering dignity of a real fighter!" Miteff, though, unlike the boxer in Requiem had already begun to fade into anonymity in the United States and in the Argentine boxing world, just a year after fighting Ali. His invisibility in the film, as an actor's double, reconfirmed that new life role. Still more compelling is the parallel between the film's plot and Miteff's already disintegrated career. Anthony Quinn's character, "Mountain" Rivera, has reached the end of his boxing days after having been knocked out by Cassius Clay in the seventh round. Among an assortment of injuries that plague the hero is a left eye dangerously close to blindness. Abused by his handlers, Rivera opts to give up his dignity and accept a wrestling contract to fight as "Big Chief Mountain" Rivera. This plot twist offers another Hollywood example of the interchangeability of socially constructed foreign, domestic, and subversive races and ethnicities in the construction of a white masculine image of the heroic through boxing in American film.

Miteff's slide was slower than Mountain Rivera's decline. He made a brief comeback in 1966 and 1967 but never won an important fight again. His last bout reinforced the brevity and mediocrity of his career. It was a loss to one of the greatest of the "great white hopes," the up-and-coming Jerry Quarry. Miteff was likely selected by Quarry's camp as a "loser," barely credible at this stage by virtue of his having fought Ali. Quarry reinforced that particular finish for Miteff's career by going on to fight as one of the most famous "losers" of the late twentieth century, falling twice to Ali, twice to Joe Frazier, and once to Ken Norton. This and Miteff's work as Quinn's double highlighted the boxer's duality as both a South American Champion of masculinity and power and, unlike Bonavena, a weak and submissive Argentine. After his retirement Miteff began to work for television producer David Susskind, who seemed to take him on as a project. Miteff served as Susskind's chauffeur and in other menial capacities. Like Joe Louis, though under still less auspicious circumstances, Miteff played on his past fame to work as a hotel greeter. In 1973, New York's Summit Hotel advertised in Argentina that hotel guests would benefit from Miteff accompanying them on shopping expeditions in Manhattan and, as a result, would benefit from special 
purchase discounts.

As he became more and more distanced from boxing, Miteff increasingly assumed the identity of an exiled Argentine fighter, broken by the American boxing world. According to the Celedonio Lima, Miteff warned other Argentine fighters newly arrived in the United States: "He asked me 'what are you doing negrito? What are you doing here [in the United States]? Are you nuts? They're going to destroy you."' Lima responded with Hollywood-like naiveté and tenacity, "I told him, 'no Miteff, hang on. I have a manager. I've come [to the United States] as a resident and with all expenses paid. I didn't come here to beg." 52

Alejandro Lavorante's case parallels that of other Argentines who entered the American market to fight and were battered by the sport. In April 1964, after eighteen months in a coma and a three-year boxing career in the United States, Lavorante died in Rosario at twenty-eight years of age. Could Lavorante have been protected from the circumstances that led to his tragic death? What is clear in this case as in others is the Argentine boxer's role and identity in the United States as a boxing commodity, the property of a manager. ${ }^{53}$

Jack Dempsey "discovered" Lavorante and recommended him to the manager Paul "Pinkie" George as a new Argentine for the American market. ${ }^{54}$ George worked Lavorante for every penny he could produce. He quickly built up the Argentine's reputation in the press as a genuine contender. Put up against four weak opponents in less than a month during September and October 1959 in Texas, Lavorante scored four convincing victories, three by knock-out. In his fourth fight, the Argentine faced his first real opponent in Roy Harris. Harris had won twenty-eight of twenty-nine fights, his only loss coming in a hard fought match with world champion Floyd Patterson the year before. Harris took advantage of Lavorante's inexperience and errors to score a difficult win. Pinkie George parlayed the loss into a media victory for his charge, who managed to go ten rounds with Harris. Lavorante later claimed to have chosen Harris as his opponent. In keeping with this version of events, he told the media that he had made a mistake and that he had not been ready for a fighter as strong as Harris had been. In future, he would be more cautious in who he fought..$^{55}$

That more thoughtful approach to Lavorante's career never came. It is unlikely that Lavorante chose Harris and just as unlikely that he had much to say about those who followed. Pinkie George had made a career in the 1930s picking boxers to lose against Joe Louis. Now, almost certainly without Lavorante's knowledge, George used the Harris fight and the notoriety it brought his boxer to work the Argentine for the short term. George undermined the prospect of an eventual title shot for Lavorante by always putting him up against more experienced and better boxers, rather than bringing him along slowly (as had Louis's handlers) against weaker opponents. Even so, Lavorante won for a time gaining the attention of the press for his height, his youth, and his good looks. In May 1960, when he knocked Jake Williams out in the sixth round, the Los Angeles Times called him 
the "new bull of the pampas." 56

In 1961, when George agreed to have Lavorante fight Zora Folley, ranked third in the world, many were skeptical of the Argentine's chances. But when Lavorante won by knockout he assumed Folley's number three spot and transformed himself into a challenger for Floyd Patterson's world title. ${ }^{57}$ In 1962, however, the Argentine suffered three devastating and violent losses. On 24 March 1962, six days before Lavorante was scheduled to fight the legendary Archie Moore, the welterweight Emile Griffith fought the Cuban Benny "Kid" Paret for the world title that the Cuban had taken from him six months before. In the twelfth round, Griffith landed twenty-three punches in less than nine seconds. Paret fell to the mat, went into a coma, and died ten days later. It was the first live television airing of a fatal injury in the ring. The media speculated inconclusively on what impact Paret-Griffith would have on Moore-Lavorante. In the latter fight, Moore dominated and in the tenth round the referee stopped the bout. A bloodied Lavorante was carried from the ring. While the California Boxing Commission later declared Lavorante free of serious injury from the fight, in the immediate aftermath of Moore's victory, for its violence, the media likened the fight to ParetGriffith as an atrocity. ${ }^{58}$

After Lavorante's recovery, in a strange twist, Pinkie George arranged for the Argentine to train under Archie Moore, an American boxer who had fought more often in Argentina than Lavorante. Citing Ernest Hemingway, Moore told the Irish Free Press that he felt for Lavorante what a safari hunter feels for a beautiful animal. At the same time, and though Lavorante did not in the end travel to Moore's San Diego training camp, Moore spoke of the Argentine's raw power and his potential to become world champion. ${ }^{59}$ Pinkie George, meantime, set about finding a new rival. In light of Lavorante's drubbing at the hands of Moore, most managers would have sought weak rivals for the foreseeable future. George chose the twenty-year-old Cassius Clay. Were his client to lose this time, George told the press, he would be back in the "minor leagues."

Many in the media and beyond were hoping that the Argentine would win to silence the "Louisville Lip." Writing for the Los Angeles Times, and with reference to Clay's supposed weak points, John Hay predicted a Lavorante victory in the fifth or the seventh round. ${ }^{61}$ With characteristic bravura, Clay told reporters that in the ring Lavorante would think he had been hit by a tornado. He predicted correctly that he would knock Lavorante out in the fifth then claimed after the fight that he might have finished off Lavorante earlier but had wanted to stick to his prediction. ${ }^{62}$

Lavorante and those around him were grim after the fight. The Argentine, his face once again mauled by a superior American opponent, made no excuses. His opponent had simply been too fast. The Los Angeles Times reminded readers of Pinkie George's warning: The minor leagues were where Lavorante now belonged. ${ }^{63}$ George was mercenary. It might be time, he reflected, for his 
boxer to retire and go home. But, likely seeing the opportunity for more money to be made, George quickly reversed himself. Only two months later, Lavorante fought Johnny Riggins. Coming off a string of losses, Riggins was chosen as a loser and a starting point for Lavorante's supposed return to contention. This time, Lavorante fared well early in the fight but again, ran into trouble in the fifth. Riggins knocked him unconscious in the following round and once again, Lavorante had to be carried out of the ring on a stretcher. ${ }^{64}$

Lavorante went into a coma and underwent a four-hour operation the next day. Pinkie George went into damage control, denying speculation that Lavorante had fought injured and too soon after his loss to Ali. But it was revealed that after the Ali fight, an electro-encephalogram that should have been performed on Lavorante had never been done. Lavorante remained in a coma for months. His mother and brother flew from Argentina to be by his side. In February 1963, seven months after the fight, Lavorante's father traveled to Los Angeles to bring his still comatose son back to Argentina. He hoped that once home, Lavorante might experience a miraculous recovery and return to life. But before they could return to Argentina the Lavorante family had to overcome the objections of physicians who feared the trip could be fatal to the boxer. They also had to face the depletion of what was left of Lavorante's limited savings. Lavorante had never been paid for his fight with Archie Moore. A judge had frozen the boxer's winnings pending an investigation of Pinkie George for illicit practices in his wrestling ventures. Once a second judge had released Lavorante's savings to his father, outstanding hospital bills had been settled, and income tax for 1962 had been paid, Lavorante was left with less than $\$ 5000$ with which to return to Argentina. ${ }^{65}$

When Lavorante died in April 1964, sports writers bundled his case with those of Kid Paret and Davey Moore, another boxer who had died from injuries sustained in the ring. There were new calls for better protection for boxers. ${ }^{66}$ Pinkie George expressed shock. Lavorante had been like a son for him, had been such a good looking kid, "a real gentleman." George blamed the family for Lavorante's death: He would have received better care had he remained in the United States. While George did his best to absolve himself of any responsibility for Lavorante's death, writer Jim Murray compared the boxer in his last fight to a child playing in traffic or a blind man walking into the wall-a spectacle that people had been willing to pay to see. Pinkie George had fought Lavorante to death. All along the media had identified Lavorante as a contender, inflating the Argentine's chances for a world championship. George sensed the dichotomy and took advantage of it almost always matching Lavorante against superior opponents in the hopes of making short term profits with little concern over the medium or long term. ${ }^{68}$ 
Argentine boxers in Argentina through an American prism

Argentines lost sight of Miteff, Lavorante, Celodonio Lima, and others whose star rose and fell quickly; the majority of the Argentine fighters who went to the United States remained there in poverty and obscurity. The attention of Argentine fans was focused on champions with staying power. "The masculinities that are implicated in the practice of boxing," writes the sociologist Kath Woodward, "are about fantasy, mythology and the invocation of legend." ${ }^{\circ 9}$ On the public stage, Miteff, Lavorante, and their handlers had sought mythological and super-masculine status. Like a majority of Argentine boxers in the United States, they had failed. Argentine fans were more swayed over the long term by the champions who achieved a legendary ideal and identity. By the mid-1970s, despite the falls of Miteff, Lavorante, and others, the experience of Argentine boxers in the United States had forged a sense among Argentines that "their" boxers were integral to the histories and mythologies of the American boxing world — a belief that in turn shaped boxing cultures in Argentina. In a 1968 overview of the best boxers in Argentina, the Buenos Aires news magazine Primera Plana (pitched to what editors believed was a sophisticated readership), considered the careers of Nicolino Locche, Ramón La Cruz, Horacio Accavallo, and Carlos Monzón, among others. But none was given the attention that heavyweight Ringo Bonavena received, despite that Bonavena was arguably the least talented of those examined. Bonavena's fame and importance came in part from his status as a heavyweight. But more important was his professional trajectory in the United States, fighting American boxers. The logic began with a nationalist approach to the sport. According to the journalist Ricardo Frascara, since Horacio Accavallo's world championship victory in Japan in 1966, and based on World Boxing Association (WBA) rankings, Argentina had become a world power in boxing surpassed only by the United States. ${ }^{70}$ Frascara constructed Argentine boxing as a function of race and geography. In the WBA rankings, the Americans dominated the heavier weight classes while, as always, Asians ruled among smaller boxers. Even so, Argentina had more top ranked boxers (ten) than any other country but the United States and Japan. This was mitigated by the representation of Argentine boxing contenders in all categories, whereas there were no Japanese fighters in the higher classes. $^{71}$

By 1970, Bonavena, though proudly Argentine, and reflecting popular national pride in his home country, had cast his public persona in the mold of how Argentines understood the image of a successful American fighter. The key model was Muhammad Ali-loud, confident, and with a professional frame of reference grounded in the United States. In 1971, between his Madison Square Garden fights with Ali (1971) and Floyd Patterson (1972) Bonavena told reporter Bernardo Gordon that he was happy to be back in the United States and ready to take on Patterson. Asked about the prospects of Argentine heavyweights, 
Bonavena responded that "there's nobody." On national champion Miguel Angel Páez, South American champion Eduardo Corletti, and contender Alberto Lovell, none were in a position, according to Bonavena, to continue fighting. At the prospect of a fight with Corletti in Montevideo, Bonavena was dismissive. To prepare for Patterson, he would train in the United States where he could get adequate sparring partners and other conditions necessary to train effectively, and the best chance for a title shot. ${ }^{72}$

As described by non-Argentine journalists, Argentine boxers were less larger-than-life. In Argentina, Víctor Galíndez was portrayed and perceived through the late-1970s in colorful extremes. He was at once the buffoon unable to control his weight and the almost superhuman fighter who had conquered Madison Square Garden. In the American press, he was simply a first rate boxer with problems outside of the ring. The Ring en Español (RE) was a Spanish-language version of the popular English-language boxing magazine The Ring. RE was sold throughout Latin America in the 1970s, including Argentina, and focused more than its English language sister on Latin American fighters. In RE, Galindez figured repeatedly as a strong fighter with problems concentrating his talents in the ring. In both his athletic prowess and his human weaknesses, RE portrayed Galíndez as less remarkable than did the Argentine media. Moreover, despite the nationalism of Argentine fans, in RE and other non Argentine venues, Argentine boxing was cast as less significant than its Panamanian and Puerto Rican equivalents, and at times, as equivalent to boxing in Peru or other Latin American countries. $^{73}$

Outside Argentina, Argentine champions were not nearly as highly regarded as in their homeland. A brilliant boxer by any standard, Carlos Monzón was cast in superlatives in the Argentine press. In RE and other American publications he was a great boxer among many. In Argentina, fans lionized super bantamweight Sergio Victor Palma in part for his "American" triumph - the first Argentine to win a world championship in the United States and the fact that his victory came against an American and Olympic champion, Leo Randolph. But outside Argentina, his stature was far less significant. RE regularly devoted more attention and deference to his competitors Jeff Chandler and Wilfredo Gomez. ${ }^{74}$

Argentine fans understood and evaluated their boxing world through American prisms and touchstones. A giant of the Argentine fight world, promoter and Luna Park owner Tito Lectoure, enhanced his reputation by his growing connections with American boxing. In 1969, the Argentine press covered Lectoure's visit to the annual meeting of the WBA in Utah where he negotiated several fights including Nicolino Locche-Adolph Pruitt and Carlos Cañete-Hiroshi Kobayashi. ${ }^{75}$ Ten years later, Lectoure used an anecdote from the United States to illustrate both his familiarity with American boxing and to suggest that the Argentine boxing world was perhaps not as cut throat. Lectoure contrasted himself with the stereotypical hard American boxing promoter. He explained to a 
reporter that he had known an American twenty years ago whom he had asked whether he helped advise boxers how to invest their winnings. "He told me "look, as a manager, my obligation is to make as much money as I can for my boxer, and have him spend it as fast as possible. The more he spends, the more he'll fight. They always need to fight." 76 Lectoure, by contrast, explained his own relationship with boxers as more caring and more human-in essence, more "Argentine."

In its first years in Argentina, television proved an essentially American medium and offered influential lessons about the commercialization process of TV, the imported means of profiting from programming (advertising on a US model), and in the nature of the programming, which was often imitative of shows in the United States. Despite that relatively few Argentines had access to the medium through the 1960s, the journalist Washington Rivera hosted the show "Campeones en el Ring" from 1956 to 1962. Sponsored by an American company, Gillette, the weekly show aired on Canal 9 on Sundays at 10:30 PM. It highlighted "La pelea de la Semana" in "la meca del boxeo: Estados Unidos." The show not only reported on boxing from the United States but contributed to the ongoing lionization of American boxing. ${ }^{77}$

In 1975, Rodolfo C. Quebleen reported to Argentine boxing fans on the history of Madison Square Garden, which represented, according to the author, boxing in the United States. The story began with the triumph of Argentine boxing in New York, as nothing less than the salvation of the storied arena as a boxing venue. For several months, Quebleen wrote, Madison Square Garden had remained closed to boxing. What saved American boxing was the card on 30 June 1975, when Argentine middleweight Carlos Monzón won the title from American Tony Licata in a WBA world title bout, and when light heavyweight Victor Galíndez defeated fellow Argentine Jorge Victor Ahumada for the WBA world championship. Quebleen's version of Madison Square Garden's past, present, and future starts with 30 June 1975 as a fulcrum, seen through crucial Argentina-related reference points. On 8 September 1975, for example, Tom Bethea fought Angel Oquendo, Víctor Galíndez's "Puerto Rican rival." Upcoming was a card featuring Mike Quarry, brother of Jerry. Madison Square Garden and Argentine boxing were intimately linked in the Argentine popular imagination. ${ }^{78}$

By any standard, the 30 June card at Madison Square Garden was momentous. Organized by Don King, the feature event took place in Kuala Lumpur. Muhammad Ali's fight with Joe Bugner was broadcast live by closed circuit to Garden fans. Fourteen years earlier, the fight promoter Carl Eaton had explained that a Miteff-Lavorante fight would never have generated much interest among American fans in that the two fighters were Argentines. ${ }^{79}$ Now, three Argentines were fighting at the Garden, two of them against each other. As such, all of the mythology and suspense built into their identities as Argentines could be brought to bear by their handlers and the media. Unlike Miteff and Lavorante, Monzón and Galíndez had not moved to or made a career in the United States. 
Of the three Argentines who fought that night, Jorge Ahumada was the only one who had come to train in North America. Ahumada had arrived in 1973. He worked under Gil Clancy who had managed Miteff and had trained Bonavena. Despite his "American" preparation and training, among the Argentines fighting, Ahumada was the only loser that night.

Unlike that of Miteff or Lavorante, the media and promoters constructed Monzón's image as that of a champion. He was an Argentine who had made his name in Europe, a star, a champion who had contributed to the weakening of American boxing - and Cold War era American masculinity-by taking the important middle weight title from the United States. Despite that a closed circuit Ali was the headliner on 30 June, the New York Times identified the "real" headliner as Monzón. ${ }^{80}$ Also unlike Miteff, Lavorante, or Bonavena, Monzón's identity as an Argentine outsider in the United States was tied to the boxer's indifference toward his surroundings. Monzón seemed bored and impatient to Americans at his press conference before the fight. According to Quebleen, as quoted in the New York Times, Madison Square Garden made no difference to Monzón. "He don't know anything about Graziano." Quebleen was quoted as saying in his halting English. "He only know Ray Robinson by movies." 11

Monzón's relative disinterest in the United States was no accident. For Americans, it marked anxiety over an unhappy loss of supremacy for the United States in the world of boxing. A year earlier, when the WBA had withdrawn Monzón's world title, Tito Lectoure had denounced the move as an "American" tactic and, more specifically, a strategy on the part of Madison Square Garden designed to rob Argentina of a title. ${ }^{82}$ In the context of a perceived decline in American boxing supremacy, The Ring had wondered why good boxers were coming to the United States in decreasing numbers. Not long after each of Miteff, Lavorante, and Bonavena had come to the United States in search of boxing glory, Americans lost their near monopoly on world championship fights. ${ }^{83}$

\section{Conclusion: Boxing and Empire}

Whether or not the bilateral US relationship with Argentina can be classed "imperial" is less significant than how US imperial dominance in the Americas extended to Argentina in economic, military, and cultural structures equivalent to those fixed on societies subject to the zenith of US-imposed violence. Carlos Monzón, Sergio Victor Palma, and other "American style" boxers were integrated in two ways into a violently repressive long-term military assault on Argentine society. First, they were stalwarts of political "neutrality." At the height of Argentina's "Dirty War" in the late 1970s, as public figures, famous boxers behaved in a manner that helped confirm the military's myth of political normalcy. Like boxers in Europe or the United States, they trained hard, fought successfully, and were photographed enjoying a sumptuous lifestyle. They expressed precisely the image that the mili- 
tary government sought to promote at home and abroad - a prosperous, stable, modern Argentina, where mounting reports of human rights abuses represented the rantings of Communists and other "malcontents."

In 1978, on the eve of the Soviet invasion of Afghanistan and the USled boycott of the 1980 Moscow Olympic games, the Argentine military government hosted the World Cup of Soccer as a showcase for Argentine normalcy, progress, and modernity. At a time when Cold War tensions were frequently expressed through sport-related political image building, prominent Argentine boxers proved willing to take part in the propaganda machine of the Argentine military as it prosecuted a vicious internal war in the name of US-led international anti-Communism. Both Monzón and Palma accepted the public accolades of military leaders. After a model used with great success by US army with Joe Louis $^{84}$ — a model equally notorious for its failure with Muhammad Ali ${ }^{85}$-Monzón and Palma were flown by the Argentine military to northwest Argentina where they gave displays for soldiers fighting a war against a largely invented leftist insurgency, the phantom insurgency that proved the excuse for the military's internal war.

In the United States, the Cold War era popular apogee of professional boxing in the 1950s and 1960s coincided with the arrival of a number of prominent, constructed Argentine boxers in the United States. In Guatemala, in Iran, and most important in Vietnam, it also dovetailed with a new apogee in the humiliation and degradation of subject peoples as part of the exercise of imperial control. ${ }^{86}$ In its violence in and out of the ring; in the myths, narratives, and histories of its participants; and in the constructions of Argentine and other boxers, boxing illustrated an increasingly ferocious American demonization of foreign "enemies" where enmity linked purported racial and political subversions.

The general decline of boxing in popular culture in the US, Argentina, and other countries since the 1980s weakened its powerful political and cultural imagery. Although less pervasive, the American portrayal of "the other" in terms of national and racial exoticism is still present in the smaller world of boxing. "Looks Russian, Prays Jewish, and Fights Black" reads the tagline of twenty-fiveyear-old up-and-coming welterweight Dmitryi Salita. Born in Ukraine and raised in Brooklyn, the symbols of Salita's Jewish Orthodox faith are displayed everywhere possible, starting with his nickname "Star of David." Reminiscent of a long tradition of Jewish boxing in America that faded out after the 1940s, in today's boxing scene Salita is as unusual as Firpo was in the 1920s. The exotization of the boxers' racial, ethnic and national identities still shows America's suspicion of the subversive other.

Although a number of Argentine boxers occasionally fight in the United States, including some who develop their careers there, the years of a notable Argentine presence in American rings are over. The recent brief and surprising success of welterweight Carlos Baldomir at Madison Square Garden revived a 
selective memory of greatness, the sense that Argentine boxers were still making history in the United States. At the age of thirty-four, Baldomir surprisingly upset world champion Zab Judah to win the world title. Astonished, Baldomir called his own triumph "better than the Cinderella story." The Argentine media tied Baldomir's victory to a long legacy of Argentine impact on US boxing, and more specifically to that impact in Madison Square Garden. While the American media recognized the unexpectedness of the upset, Baldomir's win was read by the Argentine daily newspaper Página/12 as a hero's challenge to promoter Don King and the American boxing establishment: "[A] worker from Santa Fe, expert in injustices and toughened by suffering, shook the foundations of a multimillionaire business." In a dwindling boxing world, Argentines still want to see "their" boxers as leading actors. ${ }^{87}$

\section{Notes}

1. Alan McPherson, 'From 'Punks' to Geopoliticians: US and Panamanian Teenagers and the 1964 Canal Zone Riots,” The Americas, 58, no. 3 (2002): 395-418; Renato Constantino, "The Miseducation of the Filipino," in Angel Velasco Shaw and Luis H. Francia, eds., Vestiges of War: The Philippine-American War and the Aftermath of an Imperial Dream, 1899-1999 (New York: New York University Press, 2002), 177-192.

2. See, for example, “'Don't Sell things, Sell Effects': Overseas Influences in New Zealand Department Stores, 1909-1956,” Business History Review, 77, no.2 (Summer 2003): 265-289. 3. Paul J. Dosal, Doing Business with the Dictators: A Political History of United Fruit in Guatemala, 1899-1944 (Wilmington: SR Books, 1993), 231.

4. Michael Gonzalez-Cruz, "The US Invasion of Puerto Rico: Occupation and Resistance to the Colonial State, 1898 to the Present," Latin American Perspectives, 25, no. 5 (September 1998): 726; Dennis Merrill, "Negotiating Cold War Paradise: US Tourism, Economic Planning, and Cultural Modernity in Twentieth-Century Puerto Rico," Diplomatic History, 25, no. 2 (Spring 2001): 179-214; Eric Paul Roorda, "The Cult of the Airplane among US Military Men and Dominicans during the US Occupation and the Trujillo Regime," in Gilbert M. Joseph, Catherine C. LeGrand, and Ricardo D. Salvatore, eds., Close Encounters of Empire: Writing the Cultural History of US-Latin American Relations (Durham: Duke University Press, 1998), 269-310; John Lindsay-Poland, Emperors in the Jungle: The Hidden History of the US in Panama (Durham: Duke University Press, 2003).

5. Helen Delpar, The Enormous Vogue of Things Mexican: Cultural Relations Between the United States and Mexico, 1920-1935 (Tuscaloosa: University of Alabama Press, 1992), 198-201.

6. Penny M. Von Eschen, "'Satchmo Blows Up the World': Jazz, Race, and Empire during the Cold War," in Reinhold Wagnleitner and Elaine Tyler May, eds., "Here, There and Everywhere": The Foreign Politics of American Popular Culture (Hannover: University Press of New England, 2000), 164.

7. Reinhold Wagnleitner, “The Empire of Fun, or Talkin' Soviet Union Blues: The Sound of Freedom and US Cultural Hegemony in Europe," Diplomatic History, 23, no. 3 (Summer 1999): 499-425; Robin D. Moore, Nationalizing Blackness: Afrocubanismo and Artistic Revolution in Havana, 1920-1940 (Pittsburgh: University of Pittsburgh Press, 1997), 112-113.

8. Woody Register, The Kid of Coney Island: Fred Thompson and the Rise of American Amusements (New York: Oxford University Press, 2003), 7-10, 17. 
9. After 1985, as boxing declined as a widely viewed, "popular" sport in both Argentina and the United States, so too did the image of the Argentine boxer disappear from the popular American imagination.

10. Brian Stoddart, "Sport, Cultural Imperialism, and Colonial Response in the British Empire," Comparative Studies in Society and History, 30, no. 4 (October 1988): 650.

11. Edward J. Recchia, "Martin Scorcese's Raging Bull: In Violence Veritas?" Aethlon, 7, no. 2 (Spring 1990): 21-31; Leger Grindon, "Body and Soul: The Structure of Meaning in the Boxing Film Genre," Cinema Journal, 35, no. 4 (Summer 1996): 54-69.

12. Delia Konzett, "War and Orientalism in Hollywood Combat Film," Quarterly Review of Film and Video, 21 (2004): 338.

13. Gerald Horne, "Race from Power: US Foreign Policy and the General Crisis of "White Supremacy'," Diplomatic History, 23, no. 3 (Summer 1999): 454; Eric Lott, "White Like Me: Racial Cross-Dressing and the Construction of American Whiteness," in Amy Kaplan and Donald E. Pease, eds., Cultures of United States Imperialism (Durham: Duke University Press, 1993), 474-495.

14. Andrew J. Rotter, Comrades at Odds: The United States and India, 1947-1964 (Ithaca: Cornell University Press, 2000), 150-156; Mary L. Dudziak, Cold War Civil Rights: Race and the Image of American Democracy (Princeton: Princeton University Press, 2000); Carol Anderson, Eyes Off the Prize: The United Nations and the African American Struggle for Human Rights, 1944-1955 (Cambridge: Cambridge University Press, 2003).

15. Jeffrey Montez de Oca, "'As our Muscles Get Softer: Our Missile Race Becomes Harder': Cultural Citizenship and the 'Muscle Gap',' Journal of Historical Sociology, 18, no. 3 (September 2005): 145-172; Robert D. Dean, "Masculinity as Ideology: John F. Kennedy and the Domestic Politics of Foreign Policy," Diplomatic History, 22, no. 1 (Winter 1998): 2962; Frank Costigliola, “Unceasing Pressure for Penetration': Gender, Pathology, and Emotion in George Kennan's Formation of the Cold War," Journal of American History, 83, no. 4 (March 1997): 1309-1333.

16. Demetrius W. Pearson, et al., "Sport Films: Social Dimensions Over Time, 1930-1995," Journal of Sport \& Social Issues, 27, no. 2 (May 2003): 152. During the 1940s, Hollywood studios began to produce films that represented African-Americans in a more positive light than had been the case in the past. Movies like Pinky (1949), and Home of the Brave (1949), characterized African-Americans in still one-dimensional characters, but more progressively than they tended to be viewed by most Americans. One such film, the boxing genre classic Body and Soul (1947), featured the character Ben, a noble but exploited former champion. US Federal Bureau of Investigation (FBI) special agents reacted to this variant on the clownish or thuggish African-American film type by branding Body and Soul an example of Communist subversion in Hollywood. John A. Noakes, "Racializing subversion: The FBI and the depiction of race in early Cold War movies," Ethnic and Racial Studies, 26, no. 4 (July 2003): 738-740

17. In Buenos Aires in 1954, Dempsey confessed that he still did not understand why Firpo had not been declared the winner of their 1923 fight. No. 443, Canadian Ambassador, Buenos Aires, to Secretary of State for External Affairs (Canada), 2 October 1954, 2222 M-40 (part 3.2), vol. 8051, RG 25, Library and Archives Canada, Ottawa (LAC).

18. Roger Kahn, A Flame of Pure Fire: Jack Dempsey and the Roaring '20s (New York: Harcourt Brace and Company), 325, 348.

19. Stephen G. Rabe, US Intervention in British Guiana: A Cold War Story (Chapel Hill: 
University of North Carolina Press, 2005), 185-186.

20. Tim Kawakami, Golden Boy: The Fame, Money, and Mystery of Oscar De La Hoya (Kansas City: Andrews McMeel Publishing, 1999), 18-19; Fernando Delgado, "Golden But Not Brown: Oscar De La Hoya and the Complications of Culture, Manhood, and Boxing," The International Journal of the History of Sport, 22, no. 2 (March 2005): 204.

21. Kahn, Flame, 323.

22. Delgado, "Golden But Not Brown," 201.

23. Yeidy M. Rivero, “Caribbean Negritos: Ramón Rivero, Blackface, and 'Black' Voice in Puerto Rico," Television \& New Media, 5, no. 4 (November 2004): 315-337.

24. Bruce J. Evensen, When Dempsey Fought Tunney: Heroes, Hokum, and Storytelling in the Jazz Age (Knoxville: University of Tennessee Press, 1996), xi.

25. Quoted in Kahn, Flame, 334.

26. Kahn, Flame, 326.

27. "Storm signals out for fearless Firpo," New York Times, 12 September 1923, 16.

28. Horacio Estol, Vida y Combates de Luis Angel Firpo (Buenos Aires: Editorial Bell, 1946), 234-9; "Storm signals out for fearless Firpo," New York Times, 12 September 1923, 16; "Firpo Awaits Test With Confidence," New York Times, 9 September 1923, S3; "Adviser Defends Firpo," New York Times, 23 August 1923, 11.

29. "Firpo's techniques puzzles partners," New York Times, 5 September 1923, 12.

30. "Sports through Edgren's Eyes," Washington Post, 24 July 1924, 2.

31. Cited in Evensen, When Dempsey, 46.

32. Cited in Randy Roberts, Jack Dempsey: The Manassa Mauler (Baton Rouge: Louisiana State University Press, 1979), 171.

33. Sid Sutherland, "Dempsey victory shows advantage of US ring style," Washington Post, 15 September 1923, 18.

34. The construction of Argentina and Argentines in the United States has been far less powerful or pervasive than that of Latin Americans with histories of stronger and more lasting US dominance. In addition, images of Argentina and Argentines have been more varied and nuanced than that of Mexicans or Cubans, for example. See Paul Auster, The Book of Illusions (New York: Henry Holt and Company, 2002); Louis A. Pérez, Jr., On Becoming Cuban: Identity, Nationality and Culture (New York: The Ecco Press, 1999); Helen Delpar, The Enormous Vogue of Things Mexican (Tuscaloosa: University of Alabama Press, 1992); Marta E. Savigliano, Tango and the Political Economy of Passion (Boulder: Westview Press, 1995).

35. Carlos Rotella, Cut Time: an education at the fights, (New York: Houghton Mifflin, 2003); Loïc Wacquant, "Pugs at Work: Bodily Capital and Bodily Labor Among Professional Boxers," Body and Society, 1, no. 1 (March 1995): 65-94; Loïc Wacquant, "A Fleshpeddler at Work : Power, Pain and Profit in the Prizefighting Economy," Theory and Society, 27, no. 1 (February 1998): 1-42.

36. See Michael T. Isenberg, John L. Sullivan and his America (Urbana: University of Illinois Press, 1988); Guy Reel, "Richard Fox, John L. Sullivan, and the Rise of Modern American Prize Fighting," Journalism History, 27, no. 2 (Summer 2001): 73-85; Jeffory A. Clymer, "The Market in Male Bodies: Henry James's The American and Late-Nineteenth-Century Boxing," The Henry James Review, 25 (2004): 142; Marco Maldonado and Rubén Zamora, Pasión por los guantes: Historia del Box Mexicano I (Mexico City: Clío, 2000), 12-13.

37. Argentine national ideals have been expressed far more consistently as a function of 
soccer/football than of boxing. See, for example, Juan Pablo Ferreiro, "Ni la muerte nos va a separar, desde el cielo te voy a alentar': apuntes sobre identidad y fútbol en Jujuy," in Pablo Alabarces, ed., Futbologias: fútbol, identidad y violencia en América Latina (Buenos Aires: CLACSO, 2003); Pablo Alabarces, Fútbol y patria: el fútbol y las narrativas de la nación en la Argentina (Buenos Aires: Prometeo, 2002), 57-69; Pablo Albarces, Alan Tomlinson, Christopher Young, "Argentina versus England at the France '98 World Cup: narratives of nation and the mythologizing of the popular," Media, Culture \& Society, 23 (2001): 549-554; Tony Mason, "Futbol and politics in Latin America," Race \& Class, 36, no. 4 (1995): 72-85. 38. Oscar Seleme, interview by authors, Buenos Aires, 11 July 2003.

39. See William Cronon, Nature's Metropolis: Chicago and the Great West (New York: W.W. Norton, 1991).

40. "Transplanted Corletti England's New Hope For Heavy Honors," The Ring, December 1967, 18-19, 41.

41. Andy Brown, "Lewis Bursts Corletti Bubble," The Ring, October 1968, 32.

42. Miteff lost to Ali on 7 October 1961. Rafael Tenorio, "The Economics of Professional Boxing Contracts," Journal of Sports Economics, 1, no. 4 (November 2000): 377-378.

43. Loïc Wacquant, "A Fleshpeddler at Work: Power, Pain and Profit in the Prizefighting Economy," Theory and Society, 27, no. 1 (February 1998): 1-42.

44. Alexis Miteff, interview by author, New York, 7 August 2005.

45. Sid Ziff, "Old Fighters Never Die, They All Fight Quarry," Los Angeles Times, 24 April 1967, C1.

46. "Boxing Judge Arrested on Bribery," Chicago Tribune, 3 July 1958, B1; "Wallman Links I.B.C. and Convict," New York Times, 7 December 1960, 61; Loïc Wacquant, "Whores, Slaves and Stallions: Languages of Exploitation and Accommodation among Boxers," Body \& Society, 7, no. 2-3 (2001): 181-182.

47. Alex Miteff, interview by author, New York, 15 August 2005.

48. Celedonio Lima, interview by author, Union City, New Jersey, 8 September 2005.

49. "Bonavena Fights for Long Hair," Washington Post, 20 September 1966, D2; “Suspension

Can't Stop Bonavena," Washington Post, 15 November 1970, 51.

50. Sergio Raso, interview by author, Buenos Aires, 21 July 2005.

51. Juan Martín Coggi, interview by author, Buenos Aires, 24 July 2005.

52. Celedonio Lima, interview by author, Union City, New Jersey, 14 September 2005.

53. Jeffrey Sammons, Beyond the Ring: The Role of Boxing in American Society (Urbana: University of Illinois Press, 1988), 236. See also Horacio De Marinis, 7000 Años a Puñetazos: Historia Crítica Del Boxeo (Buenos Aires: Axioma, 1974), 149-158.

54. Nat Fleischer, "Alejandro Lavorante, New Heavyweight Threat," The Ring, November 1961, 29. In a quirky postscript to the Dempsey-Firpo rivalry, Dempsey and Firpo had comanaged the Argentine heavyweight Abel Cestac after the latter reached the United States in 1945. See "Firpo's protégé arrives. But can he fight?," Washington Post, 25 July 1945, 10; "Cestac Meets Writers. Argentine to Make US Debut by Boxing Thomas Friday," New York Times, 25 July 1945, 18.

55. John De La Vega, "Manager (Who Else?) Envisions Great Ring Future for Lavorante," Los Angeles Times, 1 March 1961, C2; "Argentine makes debut here," Los Angeles Times, 19 April 1960, C5; "Latin feast, talk fight," Los Angeles Times, 17 May 1960, C5.

56. John De La Vega, "Lavorante slugs out sixth round kayo over Williams," Los Angeles Times, 18 May 1960, C5; Jim Murray, "Folley \& Folly," Los Angeles Times, 9 May 1961, C1. 
57. “Teleprompter Draws Blast From Pilot as Boxing's New Monopoly," Los Angeles Times, 2 May 1961, C3; John Hall, "Ring Scribes Vote Top Honor to Lavorante," Los Angeles Times, 13 February 1962, B3.

58. John Hall, "Moore at Crossroads - Lavorante 10-8 pick," Los Angeles Times, 30 March 1962, B1; Sid Ziff, "Same Old Main Street," Los Angeles Times, 23 March 1962, B3; John Hall, "5 000 fans watch Lavo's ring drill," Los Angeles Times, 26 March 1962, B5; "Kefauver favors tighter ring rein," New York Times, 28 March 1962, 42; John Hall, "Moore KO’s Lavorante in $10^{\text {th }}$ round," Los Angeles Times, 31 March 1962, A1; Dan Hafner, "Lavorante Tired, but Not Seriously Hurt," Los Angeles Times, 31 March 1962, A2.

59. "Another Boxing Lesson," Chicago Tribune, 31 March 1962, B1; Jim Murray, "The Art of Archie," Los Angeles Times, 2 April 1962 B1; Dan Hafner, "Lavorante Tired, but Not Seriously Hurt," Los Angeles Times, 31 March 1962, A2; John Hall, "Lavo to Take a Rest, Then Get Lessons from Arch at Salt Mines," Los Angeles Times, 1 April 1962, C1; "Archie Tabs Lavo as Next Champ," Los Angeles Times, 13 May 1962, C6.

60. "Lavorante Finds Telling Flaws in Movies of Clay-Daniels Bout," Los Angeles Times, 13 July 1962, C3.

61. John Hall, "Lavorante Tabbed for KO Win Over Clay," Los Angeles Times, 19 July 1962, B4.

62. Sid Ziff, "Clay Keeps on Talking," Los Angeles Times, 20 July 1962, B3; Bob Seizer, "Could Have Won Earlier, Says Clay," Los Angeles Times, 21 July 1962, A5.

63. John Hall, "Unbeaten Clay stops Lavorante in 5 $5^{\text {th }}$, Los Angeles Times, 21 July 1962, A1. 64. John Hall, "Critics Hail Clay as Coming Heavyweight Champion," Los Angeles Times, 22 July 1962, G6; "Lavo Faces Spoiler Foe in Riggins," Los Angeles Times, 21 September 1962, B3; Sid Ziff, "Manager Waits for Lavorante to Awake," Los Angeles Times, 27 October 1962, A2.

65. John Hall, "Lavorante Wages Battle for Life," Los Angeles Times, 23 September 1962, C1; "No Brain Test for Lavo After Clay," Los Angeles Times, 25 September 1962, C1; "Doctor Won't Assay Lavorante's Chances to Live, New York Times, 26 September 1962, 44; "Argentine Boxer Slightly Better," Washington Post, 26 September 1962, B3; "Lavorante's Ring Purse Attached," Los Angeles Times, 31 March 1962, A2; John Hall, "Fund to Cover Medical Costs for Lavorante," Los Angeles Times, 11 October 1962, B4; “Taxes Hold Up Lavorante," Washington Post, 24 April 1963, C2; “Lavorante's Coma Feared Permanent," Washington Post, 22 March 1963, D3.

66. Enrique Martín, Abeja Negra (Buenos Aires: Ediciones Cinco, 1999), 15-20.

67. "Lavorante's Death Shock to Manager," Los Angeles Times, 2 April 1964; "Manager Waits for Lavorante to Awake," Los Angeles Times, 27 October 1962.

68. "Lavo's Death Stirs Bitter Words Here," Los Angeles Times, 2 Abril 1964, B1; Jim Murray, "He didn’t belong," Los Angeles Times, 7 April 1964, B1; Loïc Wacquant, "Whores, Slaves, and Stallions: Languages of Exploitation and Accomodation Among Prizefighters," in Loïc Wacquant and Nancy Scheper-Hughes, eds., Commodifying Bodies (London: Sage Publications, 2003), 181-194.

69. Kath Woodward, "Rumbles in the Jungle: Boxing, Racialization and the Performance of Masculinity," Leisure Studies, 23, no. 1 (January 2004): 13.

70. Ricardo Frascara, “Los campeones," Primera Plana, no. 296, 27 August 1968, 40-46.

71. Frascara, "Lose campeones," 46; Luis Hernández y Alberto Oliva, "Ya comenzó el festival de Nueva Orleans," El Gráfico, no. 3075, 12 September 1978, 18-21; "Una noche en 
Filadelfia," Primera Plana, no. 312, 17 December 1968, 80-82.

72. Norberto Longo, "Ringo se prepara," K.O. Mundial, no. 931, 30 July 1971, 6.

73. "Galindez se cuidó y reconquistó la corona," The Ring en Español, June 1979, 14-16; Rai García, "Boxeo experimental en Puerto Rico," The Ring en Español, December 1979, 12-13.

74. Luis Pérez López, "Monzón: error o acierto?” The Ring en Español, October 1979, 18-20; "Leo Randolph: Tan dificil como Cardona pero distinto," Cuadrilatero, June 1980, 24-25; "Palma: un examen aprobado," K.O. Mundial, no. 1073, November 1979, 12; "Resumen 1980," The Ring en Español, January 1981, 13-16.

75. "Fructíferas gestiones del match-maker Lectoure en Estados Unidos," K.O. Mundial, no. 877, 4 September 1969, 11.

76. "Juan Carlos Lectoure: Lo que jamás conto sobre Galindez, Monzón y Corro," Gente, no. 736, 19 July 1979, 22.

77. Washington Rivera, "La radio y la television, dos 'amigos del deporte'," K.O. Mundial, no. 932, 15 August 1971, 18.

78. Rodolfo C. Quebleen, "El Madison Square Garden en busca de su pasado," K.O. Mundial, no. 1031, 30 September 1975, 6-9.

79. John De La Vega, "McCarter to Face 'New' Miteff in Olympic Bout," Los Angeles Times, 29 August 1961, C3.

80. "2 Live Title Fights at Garden May Overshadow Ali-Bugner," New York Times, 29 June 1975,169

81. Dave Anderson, “The Smoldering Middleweight Champ,” New York Times, 19 June 1975, 57.

82. "Sport News Briefs_-Madison Square Garden accused," New York Times, 24 April 1974, 38.

83. Jersey Jones, “The Wide World," The Ring, October 1964, 28-29, 48.

84. Chris Mead, Champion Joe Louis: Black Hero in White America (London: Robson Books, 1986), 212; Laren Rebecca Sklaroff, "Constructing G.I. Joe Louis: Cultural Solutions to the 'Negro Problem' during World War II," Journal of American History, vol. 89, no. 3 (December 2002): 958-983.

85. Gamal Abdel-Shehid, "Muhammad Ali: America's B Side," Journal of Sport \& Social Issues, 26, no. 3 (August 2002): 320.

86. Cas Wouters, "How Strange to Ourselves are our Feelings of Superiority and Inferiority?" Theory, Culture \& Society, 15, no. 1 (1998): 131-134.

87. Daniel Guiñazú, "Ganó con toda la pesada en contra," Página/12, 9 January 2006, sec. Líbero; Mitch Abramson, "Baldomir Upsets Judah,” New York. Times, 8 January 2006, 8.11; "Baldomir. 